\title{
KONSEPSI HUKUM PROGRESIF DALAM PENGATURAN TINDAK PIDANA KORUPSI DI INDONESIA
}

\author{
Efraim Mbomba Reda, I Nyoman Putu Budiartha, I Made Minggu Widyantara \\ Fakultas Hukum Universitas Warmadewa, Denpasar-Bali, Indonesia \\ efraimredaa@gmail.com, budiartha.fhwjurnal@gmail.com, mingguwidyantara.fhwjurnal@gmail.com
}

\begin{abstract}
Abstrak
Hukum progresif lebih mengedepankan sosiologi hukum daripada kepastian hukum yang menjadi fokus dalam positivisme hukum. Di Indonesia, hukum ini dicetuskan oleh Satjipto Rahardjo. Penelitian ini bertujuan untuk mengetahui formulasi hukum progresif dalam hukum pidana yang akan datang, dan untuk mengetahui aktualisasi konsep hukum progresif dalam pengaturan tindak pidana korupsi di Indonesia. Metode Penelitian yang digunakan adalah metode penelitian hukum normatif dengan pendekatan undang-undang dan konseptual. Teknik pengumpulan bahan hukum dalam penelitian ini adalah metode deskriptif yang bertujuan untuk memperoleh makna kenyataan yang berkaitan dengan masalah yang akan dibahas dan dipecahkan dalam penelitian ini. Hasil penelitian menunjukkan bahwa di dalam RUU KUHP saat ini, hukum progresif telah diatur, tepatnya pada Pasal 2 ayat (1) dan (2). Hukum progresif juga diatur dalam UU No. 48 tahun 2009 tentang Kekuasaan Kehakiman. Kemudian, aktualisasi hukum progresif dalam pengaturan tindak pidana korupsi di Indonesia adalah hakim dengan kekuasaan yang dimilikinya mempertimbangkan konteks sosilogis masyarakat dalam membuat keputusan. Hakim, jaksa, dan pengacara tentu dapat berdiskusi bersama dalam memberantas korupsi. Dilakukan juga upaya merekonstruksi dan meredefenisi kekuasaan penegak hukum. Pengaturan ini juga dapat mendorong KPK untuk lebih progresif dalam memberantas korupsi, juga dapat membangun penegak hukum yang memiliki moralitas sehingga dapat menjadi panutan serta meningkatkan partisipasi masyarakat semisal dengan membentuk LSM dalam mencegah maupun melawan tindakan korupsi di berbagai instansi.
\end{abstract}

Kata kunci: Hukum progresif; Tindak pidana korupsi; Pengaturan

\begin{abstract}
Progressive law puts forward the sociology of law rather than legal certainty which is the focus of legal positivism. In Indonesia, this law was coined by Satjipto Rahardjo. This study aims to determine the formulation of progressive law in future criminal law, and to determine the actualization of the concept of progressive law in regulating corruption in Indonesia. The research method used is a normative legal research method with statute and conceptual approaches. The technique of collecting legal materials in this study is a descriptive method that aims to obtain the meaning of reality related to the problems to be discussed and solved in this study. The results show that in the current Criminal Code Bill, progressive law has been regulated, to be precise in Article 2 paragraph (1) and (2). Progressive law is also regulated in Law no. 48 of 2009 concerning Judicial Power. Then, the actualization of progressive law in regulating corruption in Indonesia is a judge with the powers that take into account the sociological context of society in making decisions. Judges, prosecutors and lawyers can certainly discuss together in eradicating corruption. Efforts are also being made to reconstruct and redefine the power of law enforcement. This arrangement can also encourage the KPK to be more progressive in eradicating corruption, as well as building law enforcers who have morality so that they can become role models and increase public participation, for example by forming NGOs in preventing or fighting corruption in various agencies.
\end{abstract}

Keywords: Progressive law; Corruption crime; Settings

\section{PENDAHULUAN}

Lahirnya konsep hukum progresif yang digagas oleh Satjipto Raharjo karena refleksinya pada 60 tahun usia Indonesia sebagai negara hukum, belum menampilkan kehidupan hukum yang baik. Hukum progresif dikenal di Indonesia pada tahun 2002. Karena muncul rasa tidak puas terhadap 
praktik hukum positif lahirlah penegakan hukum progresif. Hukum progresif muncul sebagai solusi atas gagalnya aplikasi hukum positif. Ditambah keprihatinan masyarakat Indonesia dari sisi kualitas penegak hukum sejak reformasi tahun 1998. Secara fundamental hukum sebagai sebuah institusi membawa manusia pada kebahagiaan, hidup sejatera, dan adil. Kualitas hukum hanya dapat diukur dari pelayanannya pada manusia, hukum bukan institusi yang mutlak dan final (Rahardjo, 2009).

Keadilan merupakan kebutuhan hakiki semua orang, apalagi ketika dalam masalah hukum. Karena hukum progresif berfokus pada kebutuhan masyarakat bukan pada kepastian hukum, tentu membawa efek tersendiri bagi hukum pidana, secara khusus pada asas legalitas (Christianto, 2011; Hayati, 2016). Pada prinsipnya, keadilan maupun kepastian hukum adalah kedua unsur yang mesti diakomodir sebagai hukum publik yang memiliki peran penting dalam melindungi kepentingan masyarakat banyak. Karena itu, menjadi penting untuk melihat apakah konsep hukum progresif telah terartikulasikan dalam hukum positif maupun hukum yang akan datang. Menjalankan hukum tidak selalu dengan pendekatan perudang - undangan namun dengan dedikasi, empati, determinasi, serta komitmen pada persoalan bangsa, dengan demikian menghasilkan solusi - solusi kratif untuk kesejahteraan rakyat sebagaimana telah dirumuskan dalam UUD 1945.

Pada level penegakan, gerakan hukum progresif ditunjukan melalui penggunaan diskresi atau terobosoan hukum (role breaking) oleh agen penegak hukum progresif, yang memakai kewenangan dalam menjaga kepentingan golongan miskin serta marjinal. Hukum dilevel daerah maupun pelosok berjalan secara kreatif, seperti dijelaskan dalam Woodhouse, (2005) penegak hukum dilevel lokal membuat hal - hal di luar job description meraka yang kaku. Mereka menjadikan tugas lebih efektif, penyelesaian perkara lebih cepat dan pendek dengan tetap didasarkan pada hukum yang ada (Rahardjo, 2010). Dapat menjadi contoh, jaksa di Cilacap bekerja byeond the call of duty. Mereka menyelesaikan kasus korupsi sejak penyusunan BAP sampai banding ke PT lalu mengeksekusi pelaku dalam waktu empat setengah bulan. Biasanya, waktu yang digunakan untuk seperti ini adalah dua tahun.

Banyaknya kasus korupsi di masyarakat yang tidak diselesaikan secara baik serta menjadi penyebab munculnya hukum progresif. Akhirnya mulai pudar kepercayaan masyarakat pada hukum, karena banyak permasalahan tidak terpecahkan oleh hukum yang berlaku (Arif, 2019). Hukum tidak dilihat sebagai pemberi solusi justru menjadi masalah tersendiri bagi penegakan hukum. Dunia hukum kita terkesan tidak banyak berubah, justru semakin jauh dari rasa keadilan. Adagium hukum sebagai panglima hanya menjadi slogan saja. Ditengah - tengah kemisikian dan penderitaan yang dialami masyarakat Indonesia, hukum gagal memberikan keadilan. Terkesan aturan - aturan hukum hanyalah permainan bahasa, cendrung menipu dan mengecewakan. Contohnya Gayus Tambunan bisa melenggang nonton tenis di Bali serta koruptor - koruptor yang lain dapat makan serta tidur nyenyak hasil korupsi.

Berdasarkan uraian permasalahan yang telah dijabarkan di atas, maka penelitian ini dirumuskan untuk mengetahui formulasi hukum progresif dalam hukum pidana yang akan datang, dan untuk mengetahui aktualisasi konsep hukum progresif dalam pengaturan tindak pidana korupsi di Indonesia.

\section{METODE PENELITIAN}

Mengacu pada rumusan masalah, maka tipe penelitian yang digunakan dalam penulisan adalah penelitian normatif. Penelitian hukum normatif tentu menggunakan pendekatan perundang-undangan (statute approach) dan juga pendekatan konsep (conceptual approach) sebab yang diteliti adalah berbagai aturan hukum yang menjadi fokus dan merupakan tema penelitian sekaligus tema suatu penelitian, dan pendekatan penelitian yang terkadang menunjuk pada hal - hal umum atau objek objek yang menarik perhatian dari sudut pandang ilmu pengetahuan dalam hal ini ilmu hukum. Dalam penelitian ini sumber yang digunakan yaitu bahan hukum primer, sekunder, tersier. Adapun yang termasuk bahan hukum primer yaitu rancangan KUHP, undang - undang kekuasaan kehakiman, dan peraturan perundang - undangan yang lain yang mempunyai kaitan dengan masalah yang akan dipecahkan dalam penelitian ini. Sumber bahan hukum sekunder diambil dari literatur, buku - buku hukum, jurnal karya ilmiah yang membahas tentang permasalahan yang ada di dalam penelitian ini, serta sumber bahan hukum tersier adalah bahan hukum yang didapat dari penelusuran internet atau website yang bisa digunakan untuk mencari atau memecahkan masalah di dalam penelitian ini. 
Teknik pengumpulan bahan hukum yang digunakan di dalam penelitian ini yaitu studi dokumen atau juga yang biasa disebut sebagai teknik pengumpulan bahan hukum yang dilihat dari undangundang dan peraturan perundang-undangan yang terkait dengan permasalahan yang ada dalam penelitian, teknik pengumpulan bahan hukum kepustakaan yang mengumpulkan bahan dengan cara mengambil pada literatur, buku - buku, dan juga karya ilmiah yang berkaitan dengan penelitian, dan juga studi internet yaitu teknik pengumpulan bahan hukum dari internet atau sosial media yang mempunyai kaitan dengan penelitian yang diteliti. Dalam pengolahan maupun analisis menggunakan metode deskriptif. Di dalam penelitian hukum normatif, biasanya dipergunakan bahan hukum sekunder yaitu literatur - literatur, catatan perkuliahan, peraturan perundang-undangan, teori hukum serta pendapat dari beberapa hasil penelitian terdahulu.

\section{HASIL DAN PEMBAHASAN}

\section{Formulasi Hukum Progresif dalam Hukum Pidana yang akan Datang}

Pengertian hukum progresif menurut Satjipto Rahardjo antara lain:

a. Pada dasarnya manusia itu baik, sifat ini menjadi modal dalam membangun kehidupan berhukum. Hukum hanyalah instrumen atau alat yang dipakai untuk memberi manfaat baik bagi dunia dan kemanusiaan.

b. Prinsipnya hukum progresif berpihak pada rakyat, pro keadilan. Keadilan mesti ditempatkan diatas aturan - aturan formal. Penegak hukum diharapkan mampu melakukan 'mobilisasi hukum' jika aturan secara tekstual mencedrai rasa keadilan rakyat.

c. Peran publik merupakan dorongan hukum progresif. Sebab, hukum dianggap memiliki kemampuan terbatas. Mempercayakan semuanya pada kekuatan hukum adalah tindakan tidak realistis serta keliru. Kekuatan publik saat ini tenggelam dibawah dominasi hukum modern atau hukum negara. Hadirnya hukum progresif adalah memobilisasi kembali peran masyarakat.

d. Membangun negara hukum yang berhati nurani adalah cita - cita hukum progresif. Kultur yang dibangun dalam bernegara hukum yakni "the cultural primacy", yakni kultur membahagiakan rakyat. Keadaan tersebut dapat dicapai jika lebih mengutamakan "a state with conscience" dari pada "the legal structure of the state" (Rahardjo, 2009).

Saat perumusan RUU KUHP, pertentangan pengaturan 'hukum yang hidup di masyarakat pada RUU KUHP berlanjut di dalam rapat - rapat pembahasan RUU KUHP di DPR RI. Beberapa fraksi melakukan kritik, baik secara ideologis, maupun efektifitas pelaksanaan aturan tersebut. Sebagian fraksi pada pokoknya menyatakan bahwa: apabila yang dimaksud 'hukum yang hidup dalam masyarakat adalah hukum pidana adat, maka ketentuan tersebut menjadi bertentangan dengan asas legalitas, sebagaimana ditegaskan pada Pasal 1 ayat (1) RUU KUHP. Asas legalitas tidak bisa diberlakukan terhadap hukum tidak tertulis, dalam hal ini hukum pidana adat. Selain itu, keberlakuan 'hukum yang hidup di masyarakat kontradiksi dengan Pasal 1 ayat (2) tentang larangan analogi. Bahkan ada fraksi yang secara terang-terangan meminta agar pasal 2 ayat (1) tentang pengakuan bagi 'hukum yang hidup di masyarakat' untuk dicabut. Mengenai pertentangan ini, Tim Perumus RUU KUHP selalu mengemukakan pandangan bahwa pengakuan terhadap hukum yang hidup di masyarakat merupakan misi perwujudan kekhasan hukum pidana di Indonesia (dekolonialisasi).

Ditegaskan dalam UUD 1945 bahwa kekuasaan kehakiman adalah salah satu kekuasaan negara. Kekuasaan tersebut secara istimewa diberikan untuk melaksanakan fungsi yudisial. Rumusan terkait kekuasaan kehakiman belum jelas sejak negara Indonesia berdiri. Undang - undang kehakiman saat ini adalah UU No. 48 Tahun 2009 Tentang Kekuasaan Kehakiman. Hakim mempunyai kewenangan untuk mencari, menafsirkan, memaknai serta menerapkan ketentuan hukum ketika memutus suatu kasus tidak berarti tidak ada batasan yang diberlakukan. Hakim tidak dapat bertindak sebebas - bebasnya. Sebagaimana ditegaskan dalam Pasal 1 angka 1 UU No. 48 Tahun 2009 yang menyatakan bahwa hakim mesti tetap mengarahkan pandangannya pada tugas yudisial. Hakim tetap diharapkan pada tugas untuk menyeimbangkan kepastian hukum dan keadilan pada setiap putusannya. Hakim wajib untuk mendalami norma - norma yang berlaku di masyarakat sebagai ukuran objektif dan kebenaran atas putusan yang diambil didasarkan atas nilai - nilai Pancasila. Hakim dalam membuat keputusan mesti memiliki dasar hukum yang jelas serta memberikan rasa keadilan. 


\section{Aktualisasi Konsep Hukum Progresif dalam Pengaturan Tindak Pidana Korupsi di Indonesia}

Hukum progresif membutuhkan penegak hukum yang arif dan kreatif untuk menggarapnya karena kunci perubahan terletak pada penafsiran kontekstual terhadap hokum (Rahardjo, 2004). Penegak hukum yang mempertimbangan kepastian aturan dengan konteks sosiologis tentu diharapkan masyarakat. Dalam penerapan hukum progresif di pengadilan dalam rangka memberantas tindak pidana korupsi tentunya variatif. Pertama, hakim dengan kekuasaan yang dimilikinya dapat mempertimbangkan konteks sosial masyarakat dalam mengambil keputusan. Kedua, hakim, jaksa, dan pengacara tentu dapat berdiskusi bersama terkait dengan tindak pidana korupsi yang dilakukan oleh oknum serta mengambil keputusan dengan motivasi untuk memberikan keadilan sosial bagi seluruh masyarakat Indonesia demi terwujudnya Pancasila dalam kehidupan berbangsa dan bernegara. Selain kekuasaan kehakiman, kekuasaan menegakan hukum juga merupakan tugas dan wewenang kekuasaan kepolisian dan kejaksaan. Itu artinya untuk menegakan hukum adalah kewenangan bersama tiga lembaga tersebut. Oleh karena itu, menciptakan kondisi dimana lembaga penegak hukum tersebut menjadi lembaga yang independen, integral dibawah satu naungan merupakan sebuah tantangan. Pasal 8 Undang- Undang No. 2 Tahun 2002 tentang Kepolisian menjelaskan bahwa kepolisian dibahwa kepolisian berada dibawah naungan lembaga eksekutif, bukan lembaga yudikatif. Lembaga kejaksaan juga demikian, berada dibawah kekuasaan eksekutif, karena itu cendrung mudah diintervensi oleh yang berkepentingan. Karena itu, perlu upaya rekonstruksi dan redefenisi kekuasaan penegak hukum.

KPK memiliki kewenangan yang sangat besar bahkan dikatakan lembaga super body untuk memberantas korupsi. KPK memiliki wewenang dalam pengambilalihan penyelidikan, penyidikan, maupun penuntutan yang dilakukan oleh kepolisian dan kejaksaan. Pemberian kewenangan yang besar ini adalah upaya negara untuk mendukung penuh KPK memberantas korupsi. Dengan adanya kewenangan yang besar kita tentunya berharap agar KPK dapat melakukan aksi - aksi yang progresif dalam memberantas korupsi di tanah air. Bertindak benar, bertanggungjawab, transparan, cerdas dalam berpikir adalah sifat - sifat yang mesti dimiliki oleh seorang pemimpin. Instansi penegak hukum harus memiliki pemimpin yang memiliki sifat - sifat tersebut. Dengan demikian dapat menjadi anutan untuk orang banyak. Ada ragam peran tentunya yang dapat dilakukan masyarakat dalam pemberantasan korupsi. Antara lain, mengkampanyekan semangat anti korupsi, meningkatkan pendidikan moral, pengetahuan, ikut serta mengawasi pemerintahan. Jika pengawasan tidak dilakukan maka korupsi dalam terjadi. Masyarakat sangat diharapkan perannya dalam pengawasan. Misalnya dalam pembuatan peraturan. Mengantisipasi muncul peraturan yang multitafsir sehingga dapat dimanfaatkan oleh sekelompok orang untuk kepentingan tertentu maka pembuatan peraturan tersebut harus dikawal sebaik mungkin. Bagian berikut yang harus diawasi masyarakat adalah kegiatan operasional pemerintahan. Metode pengawasan bisa dilakukan dengan sistem jaringan, membentuk LSM. Jika sistem jaringan tersebut atau LSM tersebar di instansi pemerintah maka orang dapat berpikir ulang untuk melakukan korupsi.

\section{SIMPULAN DAN SARAN}

\section{Simpulan}

Berdasarkan uraian di atas, dapat disimpulkan bahwa hukum Progresif telah diformulasikan di dalam rancangan KUHP. Hukum progresif tersebut termaktub dalam RUU Kitab Undang - Undang Hukum Pidana (KUHP) Pasal 1 dan 2. Kemudian, konteks penerapan hukum progresif dalam rangka memberantas tindak pidana korupsi tentunya variatif. Pertama, hakim dengan kekuasaan yang dimilikinya dapat menggali nilai - nilai yang hidup dalam masyarakat dan mengambil keputusan. Kedua, hakim, jaksa, dan pengacara tentu dapat berdiskusi bersama terkait dengan tindak pidana korupsi yang dilakukan. Berikutnya adalah dengan kewenangan besar yang dimiliki KPK, kita tentunya berharap agar KPK dapat melakukan aksi - aksi yang progresif dalam memberantas korupsi di tanah air. Selain itu moralitas penegak hukum, partisipasi masyarakat, dan Lembaga Swadaya Masyarakat merupakan faktor yang menentukan aktualisasi hukum progresif dalam penegakan tindak pidana korupsi di Indonesia.

\section{Saran}

Adapun saran yang hendak disampaikan yakni pemerintah selaku pembuat undang-undang seharusnya memiliki pengetahuan yang memadai terkait hukum progresif agar dapat memasukan 
konsep hukum progresif dalam setiap kebijakan-kebijakan yang akan dihasilkan, terkhusus kebijakan dalam rangka menangani tindak pidana korupsi. Selanjutnya, masyarakat juga merupakan elemen penting dalam usaha memberantas tindak pidana korupsi. Kita tentunya berharap masyarakat dapat bersikap progresif dalam menghadapi persoalan korupsi. Adapun beberapa hal yang dapat dilakukan oleh masyarakat yakni meningkatkan daya kontrol terhadap kebijakan - kebijakan yang dilakukan oleh pemerintah terkait korupsi, melakukan pengawasan bagaimana berjalannya penegakan hukum, serta bisa dengan membentuk LSM sebagai fungsi kontrol. Terakhir, aparat penegak hukum dalam usaha untuk mengaktualisasikan konsep hukum progresif memiliki peran besar. Pertama, faktor kepemimpinan atau moralitas penegak hukum mencerminkan bagaimana pemimpin yang sesungguhnya. Yakni memiliki nilai - nilai universal seperti kejujuran, transparan, tegas, dll.

\section{DAFTAR PUSTAKA}

Arif, M. Y. al. (2019). Penegakan Hukum dalam Perspektif Hukum Progresif.pdf. Undang: Jurnal Hukum, 2(1), 169-192.

Christianto, H. (2011). Penafsiran Hukum Progresif Dalam Perkara Pidana. Mimbar Hukum, 23(3), $479-500$.

Hayati, N. (2016). Peralihan Hak dalam Jual Beli Hak atas Tanah (Suatu Tinjauan terhadap Perjanjian Jual Beli dalam Konsep Hukum Barat dan Hukum Adat dalam Kerangka Hukum Tanah Nasional). Lex Jurnalica, 13(3), 278-289.

Rahardjo, S. (2004). Ilmu Hukum: Pencarian, Pembebasan, dan Pencerahan. Muhammadiyah Press University.

Rahardjo, S. (2009a). Hukum Progresif: Aksi, Bukan Teks. Rajawali Pers.

Rahardjo, S. (2009b). Hukum Progresif Sebuah Sintesa Hukum Indonesia. Genta Publishing.

Rahardjo, S. (2010). Penegakan Hukum Progresif. Kompas.

Woodhouse, A. (2005). Menciptakan Peluang Keadilan: Laporan atas Studi "Village Justice in Indonesia" dan "Terobosan dalam Penegakan Hukum dan Aspirasi Reformasi Hukum di Tingkat Lokal. Bank Dunia. 